\title{
Production of a Thermostable and Alkaline Chitinase by Bacillus thuringiensis subsp. kurstaki Strain HBK-51
}

\author{
Secil Berna Kuzu, ${ }^{1}$ Hatice Korkmaz Güvenmez, ${ }^{1}$ and Aziz Akin Denizci ${ }^{2}$ \\ ${ }^{1}$ Biotechnology \& Molecular Biology Division, Department of Biology, Cukurova University, 01330 Adana, Turkey \\ ${ }^{2}$ Research Institute for Genetic Engineering and Biotechnology, The Scientific and Technical Research Council of Turkey (TUBITAK), \\ Marmara Research Center Campus, Gebze-Kocaeli 41470, Turkey
}

Correspondence should be addressed to Hatice Korkmaz Güvenmez, hkorkmaz@cu.edu.tr

Received 21 September 2012; Accepted 14 November 2012

Academic Editor: Triantafyllos Roukas

Copyright ( 2012 Secil Berna Kuzu et al. This is an open access article distributed under the Creative Commons Attribution License, which permits unrestricted use, distribution, and reproduction in any medium, provided the original work is properly cited.

This paper reports the isolation and identification of chitinase-producing Bacillus from chitin-containing wastes, production of a thermostable and alkaline chitinasese, and enzyme characterization. Bacillus thuringiensis subsp. kurstaki HBK-51 was isolated from soil and was identified. Chitinase was obtained from supernatant of B. thuringiensis HBK-51 strain and showed its optimum activity at $110^{\circ} \mathrm{C}$ and at $\mathrm{pH} 9.0$. Following 3 hours of incubation period, the enzyme showed a high level of activity at $110^{\circ} \mathrm{C}$ ( $96 \%$ remaining activity) and between $\mathrm{pH} 9.0$ and 12.0 ( $98 \%$ remaining activity). Considering these characteristics, the enzyme was described as hyperthermophile-thermostable and highly alkaline. Two bands of the enzyme weighing 50 and $125 \mathrm{kDa}$ were obtained following $12 \%$ SDS-PAGE analyses. Among the metal ions and chemicals used, $\mathrm{Ni}^{2+}(32 \%), \mathrm{K}^{+}(44 \%)$, and $\mathrm{Cu}^{2+}(56 \%)$ increased the enzyme activity while EDTA (7\%), SDS (7\%), $\mathrm{Hg}^{2+}(11 \%)$, and ethyl-acetimidate $(20 \%)$ decreased the activity of the enzyme. Bacillus thuringiensis subsp. kurstaki HBK-51 is an important strain which can be used in several biotechnological applications as a chitinase producer.

\section{Introduction}

Chitin, a linear $\beta$-(1,4)-linked $N$-acetylglucosamine (GlcNAc) polysaccharide, is the main structure component of the fungal cell wall and the exoskeletons of invertebrates, such as insects and crustaceans. Chitinase plays a variety of important roles in these organisms ranging from nutrition to defense and control of ecdysis in insects. The importance of chitinases in many biological processes makes their inhibitors important targets for potential antifungal and insecticidal agents as well as antimalarial agents [1].

It is one of the most abundant naturally occurring polysaccharides and has attracted tremendous attention in the fields of agriculture, pharmacology, and biotechnology. Chitin is the second most abundant component of biomass on earth [2]. This linear polymer can be hydrolyzed by bases, acids or enzymes, such as lysozyme, some glucanases, and chitinase. Chitinases (EC 3.2.1.14), essential enzymes catalyzing the conversion of chitin to its monomeric or oligomeric components (low-molecular-weight products), have been found in a wide range of organisms, including bacteria, plants, fungi, insects, and crustaceans. Because chitin is not found in vertebrates, it has been suggested that inhibition of chitinases may be used for the treatment of fungal infections and human parasitosis [3]. Biological control, using microorganisms to repress plant disease, offers an alternative environmentally friendly strategy for controlling agricultural phytopathogens [4]. The production of inexpensive chitinolytic enzymes is an important element in the utilization of shellfish wastes that not only solves environmental problems but also promotes the economic value of marine products, so chitinases have been studied and purified from many microorganisms, and their enzymatic properties have been investigated [5]. Global annual recovery 
of chitin from the processing of marine crustacean waste is estimated to be around 37.300 metric tons [6].

\section{Materials and Methods}

2.1. Chemicals. Chitin-Azure was (Sigma-Aldrich), PMFS, Protein Marker (BSA), CBB R-250, DMSO and the others were purchased from Merck (Germany).

2.1.1. Isolation of Bacteria. Crabs, campus soil, and compost were mixed and held to approximately 30 days outside (exposure sun, rain or etc.). After this period, sterile distilled water was added to material and homogenized. $10 \mathrm{~mL}$ supernatant wae transferred to glass tube and incubated at $80^{\circ} \mathrm{C}$ for $10 \mathrm{~min}$ to eliminate vegetative forms of bacteria. $1 \mathrm{~mL}$ sample inoculated to $10 \mathrm{~mL} \mathrm{LB}$ and incubated at $37^{\circ} \mathrm{C}$ for 6 hours and then sample was diluted $10^{-6}-10^{-7}$ fold with freshly prepared $\mathrm{LB}$, then streaked on $\mathrm{N} 1$ agar plate. After incubation at $37^{\circ} \mathrm{C}$ overnight, single colonies were selected (550 colonies in total) and stock cultures prepared [7].

2.2. Preparation of Colloidal Chitin. Preparation of colloidal chitin was performed from commercial chitin (C9752, Sigma-Aldrich Co, USA) according to Wen et al. [3] with minimal modifications. Fivegrams of chitin powder were added into $60 \mathrm{~mL}$ of concentrated HCL and left in refrigerator $\left(\right.$ at $\left.4{ }^{\circ} \mathrm{C}\right)$ overnight with vigorous stirring. The mixture was added to 2 litres of ice-cold Et-OH (95\%) with rapid stirring and kept overnight at room temperature (at $22^{\circ} \mathrm{C}$ ). The precipitate was collected by centrifugation at $6,000 \times \mathrm{g}$ $\left(4^{\circ} \mathrm{C}\right)$ for $25 \mathrm{~min}$. The precipitate was washed with sterile distilled water until the colloidal chitin became neutral $(\mathrm{pH}$ 7.0) and then stored and at $4{ }^{\circ} \mathrm{C}$ for further applications.

2.3. Screening Chitinase Producer Strains. All strains (total 550) were selected from soil including chitin wastes, tested one by one for chitinase activity on the CHDA (chitinasedetection agar). Chitinase producer strains were determined after $3-5$ days at $37^{\circ} \mathrm{C}$ by visualizing the clear zone formed surrounding of the colonies on the CHDA plate. CHDA agar, used first detection of chitinase positive strains and preparation of stock culture, by adding $10 \% \mathrm{~g}$ of colloidal chitin and $20 \mathrm{~g}$ of agar in M9 medium containing $(\mathrm{g} / \mathrm{L}) ; 0.65$ $\mathrm{NaHPO}_{4}, 1.5 \mathrm{KH}_{2} \mathrm{PO}_{4}, 0.5 \mathrm{NH}_{4} \mathrm{Cl}, 0.12 \mathrm{MgSO}_{4}, 0.005 \mathrm{CaCl}_{2}$, $0.25 \mathrm{NaCl}, \mathrm{pH}=6.5[3,8]$.

2.4. Enzyme Production. HBK-51 strain (Bacillus thuringiensis subsp. kurstaki) was used as chitinase producer. $1 \mathrm{~mL}$ of HBK-51 strain fresh culture was inoculated into $10 \mathrm{~mL}$ of LB medium (containing 1\% colloidal chitin as the sole source of $\mathrm{C}$ and $\mathrm{N}$ ) and incubated overnight at $37^{\circ} \mathrm{C}$ with shaking $\left(150 \mathrm{rev} \mathrm{min}^{-1}\right)$. The culture was transferred into a 2 litres glass bottle containing $500 \mathrm{~mL}$ M9-Medium which was supplemented with $1 \%$ colloidal chitin and incubated at $37^{\circ} \mathrm{C}$ on a rotary shaker at $150 \mathrm{rev} \mathrm{min}^{-1}$ for 3 days [3]. The culture was centrifuged for $20 \mathrm{~min}$ at $9000 \times \mathrm{g}$, at $4^{\circ} \mathrm{C}$ and supernatant was separated from cell debris. Then supernatant was filtered (with filter paper) and precipitated with Et-OH (ethyl-alcohol) [9]. All experiments were done with this enzyme preparation.

2.5. Purification of the Chitinase. Proteins in the culturesupernatant fluid were precipitated with Et-OH (ethyl-alcohol) at $-33^{\circ} \mathrm{C}$ overnight. Et-OH (ethyl-alcohol) was added $70 \%$ of the original volume of supernatant. The precipitate was recovered by centrifugation $\left(12,000 \times \mathrm{g}\left(4^{\circ} \mathrm{C}\right)\right.$ for $30 \mathrm{~min}$.), dissolved in a small amount of $0.1 \mathrm{M}$ Na-phosphate buffer ( $\mathrm{pH} 7.0)$, and stored at $4^{\circ} \mathrm{C}[10,11]$.

2.6. Measurement of Enzyme Activity. Chitinase activity was measured with chitin-azure as a substrate [12]. Enzyme solution $(0.5 \mathrm{~mL})$ was added to substrate solution $(0.5 \mathrm{~mL})$, which contained $1.0 \%$ chitin azure in a sodium acetate buffer $(100 \mathrm{mmol} / \mathrm{L}, \mathrm{pH} 7.0)$, and the mixture was incubated at $50^{\circ} \mathrm{C}$ for $30 \mathrm{~min}$. After centrifugation $(12,000 \times \mathrm{g}, 15 \mathrm{~min}$, at $4^{\circ} \mathrm{C}$ ), enzyme activity was measured at $595 \mathrm{~nm}$ absorbance using spectrophotometer. One unit of chitinase was the amount of enzyme that produced an increase of 0.01 in the absorbance $[12,13]$.

2.7. $\mathrm{pH}$ and Temperature Optima. The optimum $\mathrm{pH}$ and temperature were determined by incubation in a buffer at different $\mathrm{pH}$ values $(3.0-10.0)$ and temperatures (30$120^{\circ} \mathrm{C}$ ) under standard assay conditions using chitin-azure as the substrate. The buffers used were $50 \mathrm{mM}$ sodium acetate buffer (pH: 3.0-6.0), $50 \mathrm{mM}$ Tris- $\mathrm{HCl}$ buffer (pH: 7.0-9.0), and $50 \mathrm{mM}$ Glycine- $\mathrm{NaOH}$ buffer (pH: 10.0-12.0). The optimum temperature for enzyme activity was measured under standard assay in the range of $30-120^{\circ} \mathrm{C}$ with intervals of $10^{\circ} \mathrm{C}[14]$.

2.8. Thermal Stability. The effect of the temperature on the stability of chitinolytic enzyme was determined by exposure of the enzyme solution in $50 \mathrm{mM}$ Tris- $\mathrm{HCl}$ buffer, $\mathrm{pH}$ : 9.0 (optimum $\mathrm{pH}$ ) to different temperatures $\left(30-110^{\circ} \mathrm{C}\right.$ ) for $3 \mathrm{~h}$. The residual activity was then assayed under standard conditions using chitin-azure as the substrate $[14,15]$.

2.9. $p H$ Stability. For $\mathrm{pH}$ stability assay, the enzyme solution was preincubated for $3 \mathrm{~h}$ at room temperature in the buffers of various $\mathrm{pH}$ values $(\mathrm{pH}: 5.0-12.0)$ and then the residual activity was determined under standard conditions $[14,15]$.

2.10. Plasmid Curing. All bacteria which produced chitinase were tested with $\mathrm{EtBr}$ for plasmid elimination according to Hardy [16].

2.11. Identification of Bacillus sp. Criteria used for classification and identification of Bacillus strain HBK-51 were based on morphological [7], physiological and biochemical tests (Table 1) [17], fatty acid analyses (FAME) (SherlockMIDI Automated Microbial Identification System version 4.0, MIDI inc., Newark, DE), and 16S RNA/DNA sequence analyses $[14,18,19]$. 
TABLE 1: Morphological and physiological characteristics of chitinase-producing bacteria strain HBK-51.

\begin{tabular}{lc}
\hline Morphological characteristics & \\
Form & Rod \\
Gram stain & Positive \\
Spore & Terminal spore forming \\
Capsule & Negative \\
Motility & Positive \\
Physiological characteristics & \\
Catalase & Positive \\
Hydrolysis of starch & Positive \\
$\beta$-haemolysis & Positive \\
Cimons' Citrate & Positive \\
Hydrolysis of gelatin & Negative \\
Hydrolysis of l lecithin & Negative \\
Indol formation & Negative \\
VP-Test & Negative \\
Urease & Negative \\
\hline
\end{tabular}

2.12. 16S rRNA Gene Sequence Comparison. The 16S rRNA gene was amplified by polymerase chain reaction (PCR) with forward primers:

27F 5'-AGAGTTTGATCMTGGCTCAG-3' (8-27 position),

530F 5' -GTGCCAGAGCMGCCGCGGTAA-3' (515533 position)

and reverse primers:

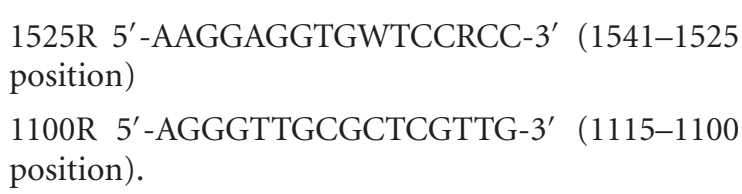

The amplified PCR product was sequenced by the Beckman Coulter-CQ 8800 model sequence analyzer with their methods. The $16 \mathrm{~S}$ rDNA sequence was aligned with other $16 \mathrm{~S}$ rDNA bacterial sequence obtained from GenBank by basic local alignment search tool (BLAST) program [20].

2.13. The Influence of Chemicals (Metal Ions, Chelators, and Detergents). The chemicals were used in two different concentrations (Table 2). These chemicals' effect on chitinolytic activity was determined by incubating $0.5 \mathrm{~mL}$ enzyme with 1-5 mM EDTA, PMSF, 1,10-Phenanthroline, ethyl-acetimidate, Phenol Gliaksol, N-Ethylmaleimide, Urea, $\mathrm{Na}_{2} \mathrm{SO}_{3}, \mathrm{NaCl}, \mathrm{CaCl}_{2}, \mathrm{ZnCl}_{2}, \mathrm{MgCl}_{2}, \mathrm{BaCl}_{2}, \mathrm{FeCl}_{3}, \mathrm{MnCl}_{2}$, $\mathrm{CuCl}_{2}, \mathrm{CoCl}_{2}, \mathrm{NiCl}_{2}, \mathrm{KCl}, \mathrm{HgCl}_{2}$, and $1-5 \%$ SDS and DMSO for $30 \mathrm{~min}$ at room temperature after which the residual activity was measured with standard assay [21].

2.14. SDS-PAGE Analyses. The enzyme molecular weight was determined with sodium dodecyl sulphate polyacrylamide gel electrophoresis (PAGE) [22]. The gel was prepared
TABLE 2: Influence of chemicals on chitinase activity.

\begin{tabular}{|c|c|c|}
\hline Chemical & Con. & Act. (\%) \\
\hline control & & 100 \\
\hline \multirow{2}{*}{ DMSO } & $1 \%$ & 92 \\
\hline & $5 \%$ & 92 \\
\hline \multirow{2}{*}{ EDTA } & $1 \mathrm{mM}$ & 95 \\
\hline & $5 \mathrm{mM}$ & 93 \\
\hline \multirow{2}{*}{ Ethyl acetimidate } & $1 \mathrm{mM}$ & 90 \\
\hline & $5 \mathrm{mM}$ & 80 \\
\hline \multirow{2}{*}{ SDS } & $1 \mathrm{mM}$ & 97 \\
\hline & $5 \mathrm{mM}$ & 93 \\
\hline \multirow{2}{*}{ Phenol Gliaksol } & $1 \mathrm{mM}$ & 92 \\
\hline & $5 \mathrm{mM}$ & 104 \\
\hline \multirow{2}{*}{ 1,10-Phenanthroline } & $1 \mathrm{mM}$ & 90 \\
\hline & $5 \mathrm{mM}$ & 100 \\
\hline \multirow{2}{*}{ N-Ethylmaleimide } & $1 \mathrm{mM}$ & 106 \\
\hline & $5 \mathrm{mM}$ & 89 \\
\hline \multirow{2}{*}{ PMSF } & $1 \mathrm{mM}$ & 108 \\
\hline & $5 \mathrm{mM}$ & 81 \\
\hline \multirow{2}{*}{ Urea } & $1 \mathrm{mM}$ & 106 \\
\hline & $5 \mathrm{mM}$ & 80 \\
\hline \multirow{2}{*}{ Na-Sulphite } & $1 \mathrm{mM}$ & 98 \\
\hline & $5 \mathrm{mM}$ & 96 \\
\hline \multirow{2}{*}{$\mathrm{MgCl}_{2}$} & $1 \mathrm{mM}$ & 100 \\
\hline & $5 \mathrm{mM}$ & 90 \\
\hline \multirow{2}{*}{$\mathrm{NaCl}_{2}$} & $1 \mathrm{mM}$ & 97 \\
\hline & $5 \mathrm{mM}$ & 93 \\
\hline \multirow{2}{*}{$\mathrm{BaCl}_{2}$} & $1 \mathrm{mM}$ & 101 \\
\hline & $5 \mathrm{mM}$ & 87 \\
\hline \multirow{2}{*}{$\mathrm{FeCl}_{3}$} & $1 \mathrm{mM}$ & 81 \\
\hline & $5 \mathrm{mM}$ & 106 \\
\hline \multirow{2}{*}{$\mathrm{MnCl}_{2}$} & $1 \mathrm{mM}$ & 118 \\
\hline & $5 \mathrm{mM}$ & 77 \\
\hline \multirow{2}{*}{$\mathrm{CuCl}_{2}$} & $1 \mathrm{mM}$ & 127 \\
\hline & $5 \mathrm{mM}$ & 155 \\
\hline \multirow{2}{*}{$\mathrm{CoCl}_{2}$} & $1 \mathrm{mM}$ & 115 \\
\hline & $5 \mathrm{mM}$ & 116 \\
\hline \multirow{2}{*}{$\mathrm{NiCl}_{2}$} & $1 \mathrm{mM}$ & 132 \\
\hline & $5 \mathrm{mM}$ & 123 \\
\hline \multirow{2}{*}{$\mathrm{ZnCl}_{2}$} & $1 \mathrm{mM}$ & 118 \\
\hline & $5 \mathrm{mM}$ & 106 \\
\hline \multirow{2}{*}{$\mathrm{KCl}_{2}$} & $1 \mathrm{mM}$ & 127 \\
\hline & $5 \mathrm{mM}$ & 144 \\
\hline \multirow{2}{*}{$\mathrm{CaCl}_{2}$} & $1 \mathrm{mM}$ & 94 \\
\hline & $5 \mathrm{mM}$ & 106 \\
\hline \multirow{2}{*}{$\mathrm{HgCl}_{2}$} & $1 \mathrm{mM}$ & 93 \\
\hline & $5 \mathrm{mM}$ & 89 \\
\hline
\end{tabular}

Con: Concentration, Act: Activity.

The enzyme was incubated with various ions and reagents at room temperature for $30 \mathrm{~min}$., then chitinase activity was assayed under standard conditions. The enzyme activity without any additive was taken as $100 \%$.

using $5 \%$ stacking gel and $12 \%$ of separating gel (Acr:Bis $=29: 1)$. After electrophoresis gel was stained with CBB-R 


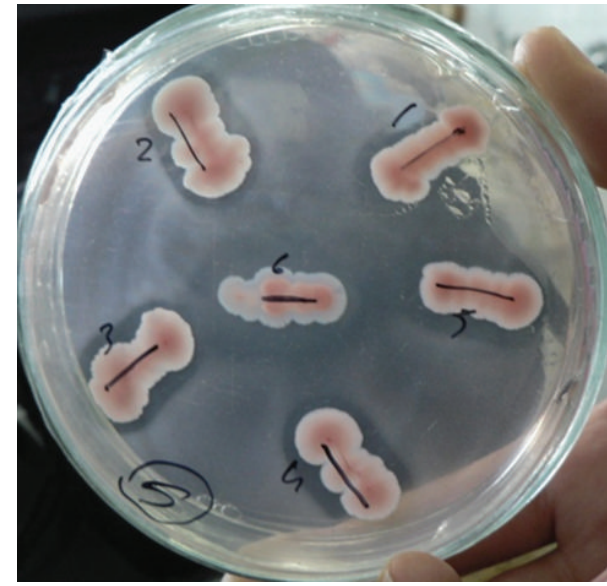

FIgURE 1: Chitinase activity on CHDA plate.

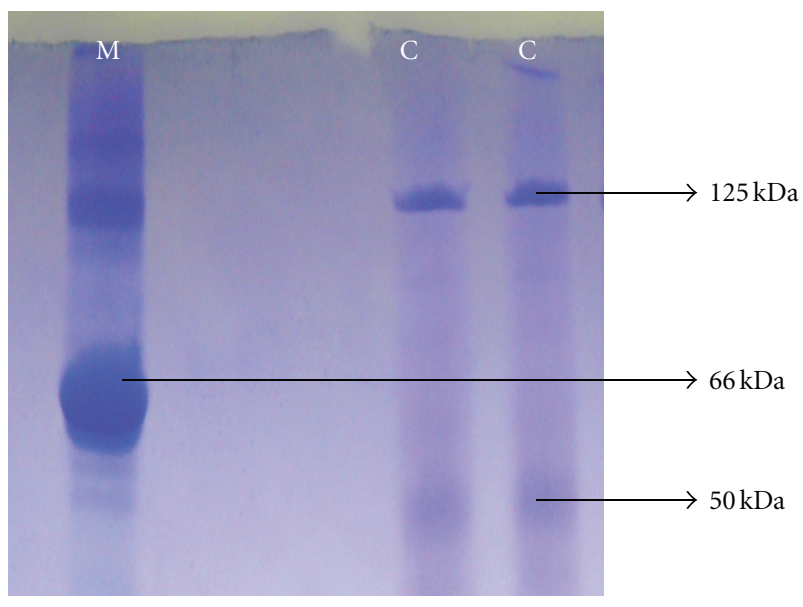

FIGURe 2: Chitinase molecular weight pattern of Bacillus thuringiensis subsp. kurstaki strain HBK-51. M: Protein Marker (BSA, 66 kDa), C: Chitinase.

250 then visualized by placing the gel to the Minibus Gel Apparatus, BSA (Sigma) was used as a MW marker.

\section{Results and Discussion}

Chitinase producing bacteria were isolated from chitin wastes on CHDA (chitinase detection agar, Figure 1) and chitinase was produced in the media containing $1 \%$ of colloidal chitin [3]. In total, 550 strains were selected from chitin wastes and tested for chitinolytic activity. After screening the strains for their ability to utilize chitin, 12 of them $(2.18 \%)$ showed chitinolytic activity. 6 strains were showed the highest hydrolysis zone $(4-10 \mathrm{~mm})$ on CHDA agar. They were termed HBK-30, HBK-36, HBK-37, HBK42, HBK-43, and HBK-51. HBK-51 strain was selected as chitinase producer.

The HBK-51 strain was identified according to morphological and physiological characteristics (are presented in Table 1) [17]. According to Bergey's Manual of Systematic Bacteriology [7], strain HBK-51 was classified as a bacteria

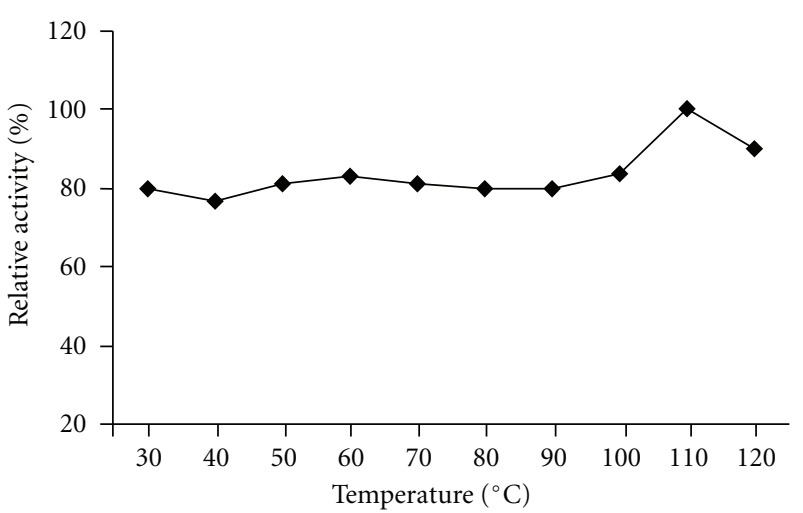

FiguRE 3: Effect of temperature on the chitinase activity.

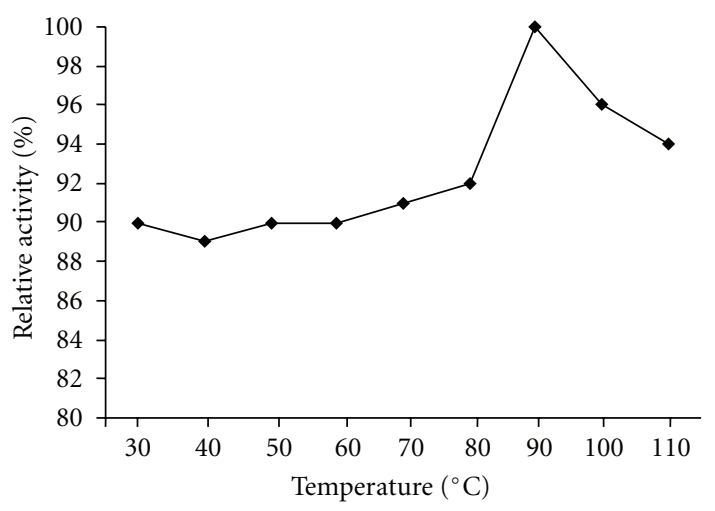

FIgURE 4: Thermal stability of chitinase.

belonging to the genus Bacillus. Further sequence analysis of the gene encoding 16S rRNA and fatty acid analyses (FAME, data not shown) confirmed the isolate as being Bacillus genus and according to BLAST confirmation, it was Bacillus thuringiensis subsp. kurstaki. Theamplified16S rRNA sequence was submitted to GenBank for possible identification. The result showed $99.00 \%$ identity with Bacillus thuringiensis subsp. kurstaki. The accession number is EU153549. Chitinolytic activity of HBK-51 on CHDA is shown in Figure 1.

According to the plasmid-curing tests, the gene of encoding chitinase of Bacillus thuringiensis subsp. kurstaki HBK-51 was located on chromosomal.

3.1. $\mathrm{pH}$ and Temperature Optima. The $\mathrm{pH}$ effect on the chitinase activity was determined using three buffer systems at various $\mathrm{pH}$ values. The HBK-51 chitinase was active at broad range of $\mathrm{pH}(3.0-10.0)$ but had optimum activity at $\mathrm{pH} 9.0$ (data shown Figure 5), when assayed with chitin azure as a substrate. On the other hand, enzyme was active from 30 to $120^{\circ} \mathrm{C}$ and exhibited maximum activity at $110^{\circ} \mathrm{C}$ (Figure 3). The enzyme was stable (after 3 hours incubation period) at $30-120^{\circ} \mathrm{C}$ and $\mathrm{pH} 9.0-12.0$ and generally, protected original activity approximately $92.4 \%$ (Figure 4 ) and $98 \%$ (Figure 6), respectively, at $90^{\circ} \mathrm{C}$ chitinase was $100 \%$ active and at $100-110^{\circ} \mathrm{C}$ had shown $96 \%$ retain activity. 


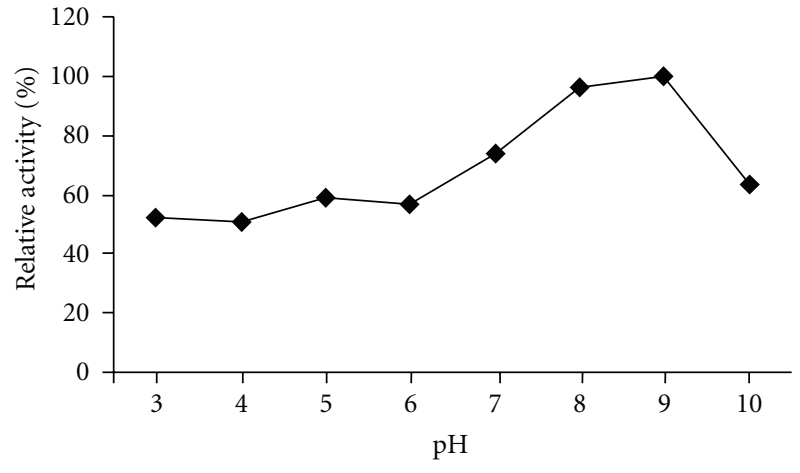

FIgURE 5: Effect of $\mathrm{pH}$ on chitinase activity.

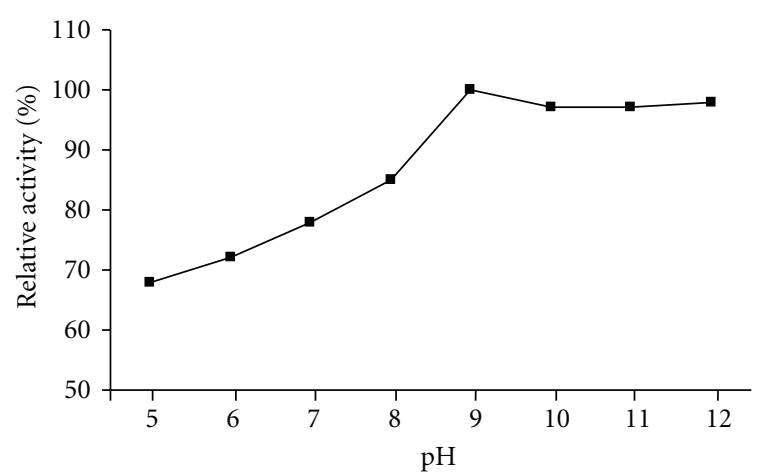

FIGURE 6: pH stability of chitinase.

Therefore, HBK-51 chitinase was called as thermostable at high temperatures. Siwayaprahm et al. [23] reported that for Bacillus circulans No. 4.1. recombinant chitinase, the optima $\mathrm{pH}$ and temperature were 7.0 and $45^{\circ} \mathrm{C}$, respectively, and it was stable in the $\mathrm{pH}$ range of 5.0-9.0 and at temperatures up to $50^{\circ} \mathrm{C}$. Lee et al. [24] reported that Bacillus sp. DAU101 chitinase had optimum activity $\mathrm{pH} 7.5$ and $60^{\circ} \mathrm{C}$, Wen et al. [3] reported chitinase activity of Bacillus sp. NCTU2 had in the range of $50-60^{\circ} \mathrm{C}$ at $\mathrm{pH}$ 7.0. Kim et al. [14] reported Serratia sp. KCK chitinase had broad range of $\mathrm{pH}(5.0-10.0)$ with an optimum value of 8.0 and $40^{\circ} \mathrm{C}$, respectively. Li et al. [25] reported Bacillus cereus strain $\mathrm{CH} 2$ had optimum activity at $\mathrm{pH} 7.1$ and temperature at $40^{\circ} \mathrm{C}$. According to these results, Bacillus thuringiensis subsp. kurstaki HBK-51 chitinase is a thermotolerant and alkaline enzyme. Guo et al. [26] reported that Thermomyces lanuginosus SY2 chitinase exhibited optimum catalytic activity at $\mathrm{pH} 4.5,55^{\circ} \mathrm{C}$ and enzyme was stable at $50^{\circ} \mathrm{C}$ and its half-life time at $65^{\circ} \mathrm{C}$ was $25 \mathrm{~min}$. On the other hand, they reported that the thermostable chitinase had major advantages over industrial catalysis for its high activity at high temperature. Thermostable chitinase could be useful for the chitin industry and biotechnological applications.

3.2. Influence of Chemicals and SDS-PAGE Analyses. The effects of various chemicals on enzyme activity were tested (Table 2) in the presence (at $1-5 \mathrm{mM}$ concentrations) of $\mathrm{Co}^{2+}, \mathrm{Zn}^{2+}, \mathrm{Ni}^{2+}, \mathrm{K}^{+}, \mathrm{Cu}^{2+}$ enzyme activity was slightly enhanced by $16 \%, 18 \%, 32 \%, 44 \%, 56 \%$, respectively. Wen et al. [3] reported that Bacillus sp. NCTU2 chitinase activity was enhanced by $\approx 100 \%$ in the presence of $10 \mathrm{mM} \mathrm{Ca}^{2+}$. In the presence of $\mathrm{Hg}^{2+}$ and $\mathrm{Cu}^{2+}$ (at $10 \mathrm{mM}$ ) enzyme activity lost by $95 \%$. Yuli et al. [27] reported that effect of metal ions on chitinase activity was quite different. In the presence of EDTA, SDS, $\mathrm{HgCl}_{2}$, ethyl=acetimidate the enzyme activity was partially inhibited by $7 \%, 7 \%, 11 \%$, $20 \%$, respectively, but (Table 2) other chemicals weakly affected enzyme activity. The enzyme molecular weight revealed as 125 and $50 \mathrm{kDa}$ (Figure 2). Similar results were indicated by the other chitinase researchers by SDS-PAGE analyses: Aeromonas sp. chitinases was different in the range of $89-120 \mathrm{kDa}$ [28], Bacillus sp. chitinase around 25-80 kDa [29], Streptomyces strain 68 chitinase, 25, 35, 67 and $200 \mathrm{kDa}$ [30], Bacillus sp. NCTU2 chitinase $36.5 \mathrm{kDa}$ [3], Bacillus cereus strain $\mathrm{CH} 2$ chitinase $15 \mathrm{kDa}$ [25], and Thermomyces lanuginosus SY2 chitinase molecular size was estimated to be $48 \mathrm{kDa}[26]$.

Chitinases have a broad spectrum of different industrial applications such as bio-control agents against plant pathogens (fungi) and insects (bio-insecticide friend with environment) and bioconversion of chitin waste to single-cell protein, Et-OH and fertilizer [14].

The thermostable chitinase had major advantages over industrial catalysis for its high activity at high temperature [26]. The properties of thermostable chitinase suggest that it could be useful for the chitin industry and biotechnological applications.

\section{References}

[1] J. N. Tabudravu, V. G. H. Eijsink, G. W. Gooday et al., "Psammaplin A, a chitinase inhibitor isolated from the Fijian marine sponge Aplysinella rhax," Bioorganic and Medicinal Chemistry, vol. 10, no. 4, pp. 1123-1128, 2002.

[2] H. S. Lee, D. S. Han, S. J. Choi et al., "Purification, characterization, and primary structure of a chitinase from Pseudomonas sp. YHS-A2," Applied Microbiology and Biotechnology, vol. 54, no. 3, pp. 397-405, 2000.

[3] C. M. Wen, C. S. Tseng, C. Y. Cheng, and Y. K. Li, "Purification, characterization and cloning of a chitinase from Bacillus sp. NCTU2," Biotechnology and Applied Biochemistry, vol. 35, no. 3, pp. 213-219, 2002.

[4] W. T. Chang, Y. C. Chen, and C. L. Jao, "Antifungal activity and enhancement of plant growth by Bacillus cereus grown on shellfish chitin wastes," Bioresource Technology, vol. 98, no. 6, pp. 1224-1230, 2007.

[5] S. Kudan and R. Pichyangkura, "Purification and characterization of thermostable chitinase from Bacillus licheniformis SK1," Applied Biochemistry and Biotechnology, vol. 157, no. 1, pp. 23-35, 2009.

[6] S. A. Shaikh and M. V. Deshpande, "Chitinolytic enzymes: their contribution to basic and applied research," World Journal of Microbiology and Biotechnology, vol. 9, no. 4, pp. 468-475, 1993.

[7] J. D. Holt, Manual of Determinative Bacteriology, Williams \& Wilkins, Baltimore, Md, USA, 1993.

[8] R. M. Cody, N. D. Davis, J. Lin, and D. Shaw, "Screening microorganisms for chitin hydrolysis and production of 
ethanol from amino sugars," Biomass, vol. 21, no. 4, pp. 285295, 1990.

[9] J. Frankowski, M. Lorito, F. Scala, R. Schmid, G. Berg, and H. Bahl, "Purification and properties of two chitinolytic enzymes of Serratia plymuthica HRO-C48," Archives of Microbiology, vol. 176, no. 6, pp. 421-426, 2001.

[10] R. A. K. Srivastava, "Purification and chemical characterization of thermostable amylases produced by Bacillus stearothermophilus," Enzyme and Microbial Technology, vol. 9, no. 12, pp. 749-754, 1987.

[11] J. Folders, J. Tommassen, L. C. van Loon, and W. Bitter, "Identification of a chitin-binding protein secreted by Pseudomonas aeruginosa," Journal of Bacteriology, vol. 182, no. 5, pp. 1257$1263,2000$.

[12] M. G. Ramírez, L. I. R. Avelizapa, N. G. R. Avelizapa, and R. C. Camarillo, "Colloidal chitin stained with Remazol Brilliant Blue R, a useful substrate to select chitinolytic microorganisms and to evaluate chitinases," Journal of Microbiological Methods, vol. 56, no. 2, pp. 213-219, 2004.

[13] N. J. R. Shih and K. A. McDonald, "Purification and characterization of chitinases from transformed callus suspension cultures of Trichosanthes kirilowii Maxim," Journal of Fermentation and Bioengineering, vol. 84, no. 1, pp. 28-34, 1997.

[14] H. S. Kim, K. N. Timmis, and P. N. Golyshin, "Characterization of a chitinolytic enzyme from Serratia sp. KCK isolated from kimchi juice," Applied Microbiology and Biotechnology, vol. 75, no. 6, pp. 1275-1283, 2007.

[15] J. Favaloro, R. Treisman, R. Kamen, L. Grosman, and K. Moldave, Methods in Enzymology, Academic Pres, New York, NY, USA, 1980.

[16] K. G. Hardy, Plasmids, The Practical Approach Serie, 1993.

[17] J. F. MacFaddin, Biochemical Tests For Identification of Medical Bacteria, Williams \& Wilkins, Baltimore, Md, USA, 2000.

[18] W. P. Chen and T. T. Kuo, "A simple and rapid method for the preparation of gram-negative bacterial genomic DNA," Nucleic Acids Research, vol. 21, no. 9, p. 2260, 1993.

[19] A. A. Denizci, D. Kazan, E. C. A. Abeln, and A. Erarslan, "Newly isolated Bacillus clausii GMBAE 42: an alkaline protease producer capable to grow under higly alkaline conditions," Journal of Applied Microbiology, vol. 96, no. 2, pp. 320-327, 2004.

[20] S. F. Altschul, W. Gish, W. Miller, E. W. Myers, and D. J. Lipman, "Basic local alignment search tool," Journal of Molecular Biology, vol. 215, no. 3, pp. 403-410, 1990.

[21] N. N. Nawani and B. P. Kapadnis, "Production dynamics and characterization of chitinolytic system of Streptomyces sp. NK1057, a well equipped chitin degrader," World Journal of Microbiology and Biotechnology, vol. 20, no. 5, pp. 487-494, 2004.

[22] D. M. Bollag, S. J. Edelstein, and M. D. Rozycki, Protein Methods, Villey-Liss Pres, 1996.

[23] P. Siwayaprahm, M. Audtho, K. Ohmiya, and C. Wiwat, "Purification and characterization of a Bacillus circulans No. 4.1 chitinase expressed in Escherichia coli," World Journal of Microbiology and Biotechnology, vol. 22, no. 4, pp. 331-335, 2006.

[24] Y. S. Lee, I. H. Park, J. S. Yoo et al., "Cloning, purification, and characterization of chitinase from Bacillus sp. DAU101," Bioresource Technology, vol. 98, no. 14, pp. 2734-2741, 2007.

[25] J. G. Li, Z. Q. Jiang, L. P. Xu, F. F. Sun, and J. H. Guo, "Characterization of chitinase secreted by Bacillus cereus strain $\mathrm{CH} 2$ and evaluation of its efficacy against Verticillium wilt of eggplant," BioControl, vol. 53, no. 6, pp. 931-944, 2008.
[26] R. F. Guo, B. S. Shi, D. C. Li, W. Ma, and Q. Wei, "Purification and characterization of a novel thermostable chitinase from Thermomyces lanuginosus SY2 and cloning of its encoding gene," Agricultural Sciences in China, vol. 7, no. 12, pp. 14581465, 2008.

[27] P. E. Yuli, M. T. Suhartono, Y. Rukayadi, J. K. Hwang, and Y. R. Pyun, "Characteristics of thermostable chitinase enzymes from the indonesian Bacillus sp.13.26," Enzyme and Microbial Technology, vol. 35, no. 2-3, pp. 147-153, 2004.

[28] M. Ueda, A. Fujiwara, T. Kawaguchi, and M. Arai, "Purification and some properties of six chitinases from Aeromonas sp. No. 10S-24," Bioscience, Biotechnology, and Biochemistry, vol. 59, no. 11, pp. 2162-2164, 1995.

[29] K. Sakai, A. Yokota, H. Kurokawa, M. Wakayama, and M. Moriguchi, "Purification and characterization of three thermostable endochitinases of Bacillus noble strain $\mathrm{MH}-$ 1 isolated from chitin containing compost," Applied and Environmental Microbiology, vol. 64, no. 9, pp. 3340-3497, 1998.

[30] R. C. Gomes, L. T. A. S. Semêdo, R. M. A. Soares, C. S. Alviano, L. F. Linhares, and R. R. R. Coelho, "Chitinolytic activity of Actinomycetes from a cerrado soil and their potential in biocontrol," Letters in Applied Microbiology, vol. 30, no. 2, pp. 146-150, 2000. 

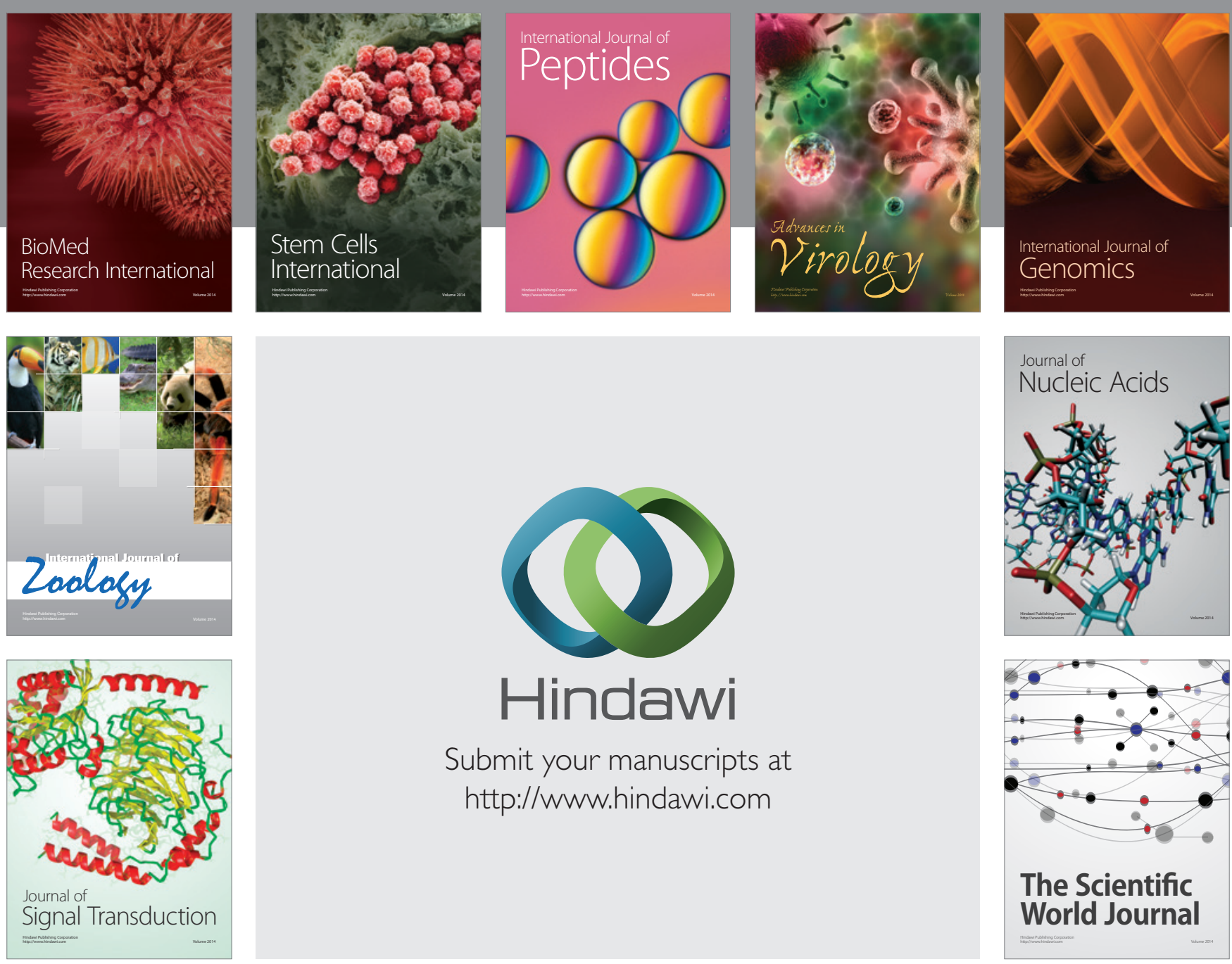

Submit your manuscripts at

http://www.hindawi.com
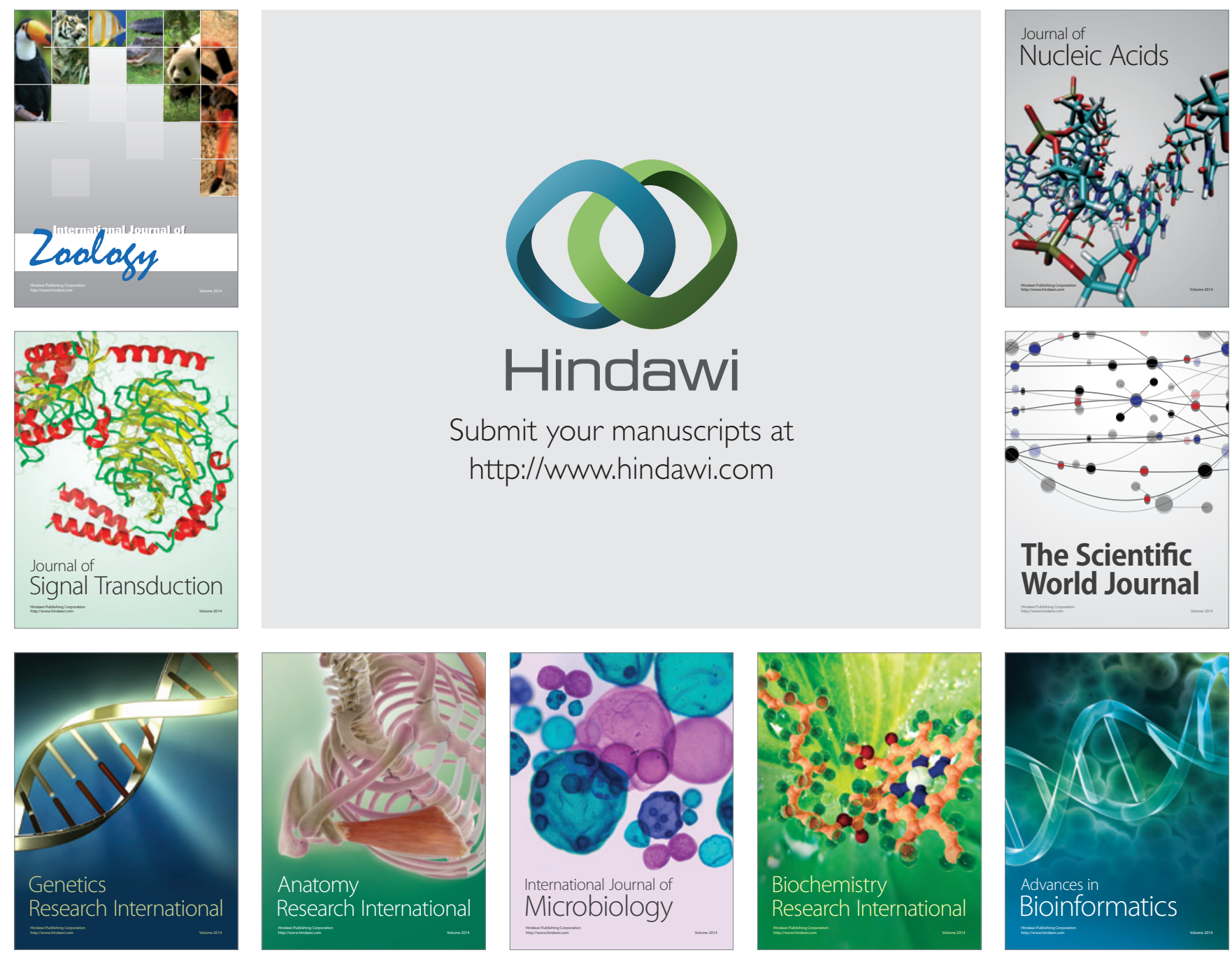

The Scientific World Journal
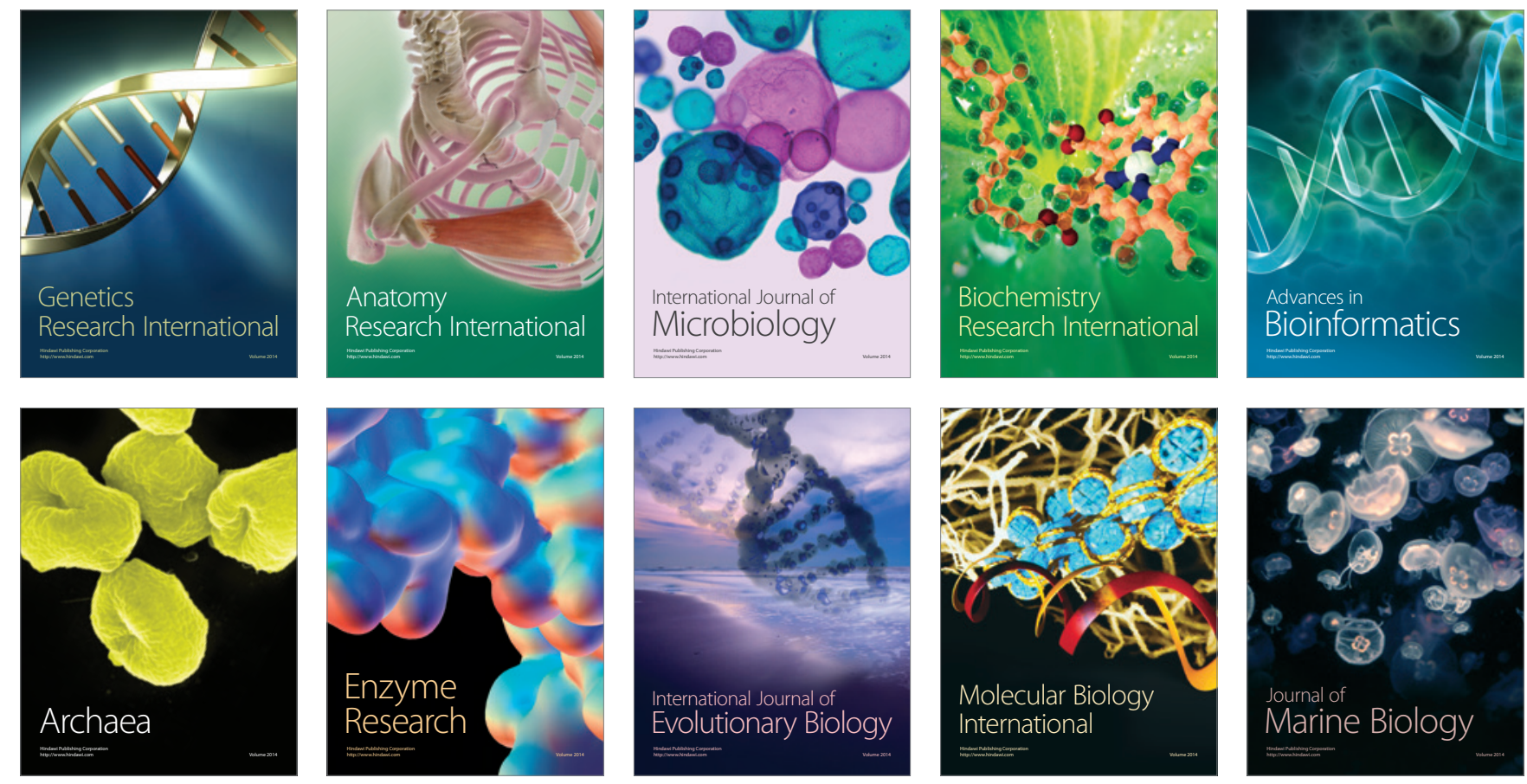